\title{
Effect of Vermicompost with Microbial Bio Inoculums on the Growth Parameter of Coriander (Coriandrum sativum L.)
}

\author{
P. Sakthivel", Alice R. P. Sujeetha, G. Ravi, A. G. Girish and P. Punnam Chander
}

National Institute of Plant Health Management, Ministry of Agriculture and Farmers Welfare, Govt. of India, Rajendranagar, Hyderabad - 500030, India

*Corresponding author

Keywords

Bio inoculant, Coriander, FYM, Organicmanure, Vermicompost,

Article Info

Accepted:

10 July 2020

Available Online:

10 August 2020

\begin{abstract}
A B S T R A C T
Vermicompost is an organic fertilizer which converts waste to wealth in a safe and healthy way as it is produced by biopotential of earthworm. It contains plant growth hormones, enzymes, microbial population, and free of harmful pathogens. Application of such a microbiologically active organic substrate may have important effects on the microbial properties of the media. A study was conducted to find out the effect of organic manures in combination with microbial bio inoculants on the growth, plant height, wet weight, dry weight, and yield of coriander. The experiment was carried out as in open field with seven treatments at National Institute of Plant Health Management, Rajendranagar, Hyderabad in December, 2019. The analysis of the variance results revealed that the effect of the type of treatments on fresh weight, number of leaves, root length, fresh weight, dry weight, chlorophyll content and biomass yield showed significant effect when compared to control. The results also showed that the interaction of vermicompost and bio inoculants were significantly enhanced the morphological character of the coriander crop. Therefore, the application of bio inoculants with any of the organic manure to be a potential source of plant nutrients which contributes the growth of coriander.
\end{abstract}

\section{Introduction}

"Sustainable agriculture" can be ensured in future with the help of organic farming systems which includes various processes of biological origin such as compost and vermin compost. Compost and vermicompost are appropriate technologies which convert waste to wealth. Vermicomposting is increasingly becoming popular as an organic farming and solid waste management technique and it produces two vital bio fertilizers, vermin compost and vermin wash (Kaur et al., 2015).
Vermicompost is an organic manure produced as the vermicast by earthworm feeding on biological waste material; plant residues (Rathore et al., 2007) and it is one of the best source of nutrients improves the physical and chemical properties of crops (Sinha et al., 2010). The vermicompost is rich in NPK and micronutrients (Palanichamy et al., 2011). Vermicompost and Biofertilizer are also useful substitutes to inorganic fertilizers which improves the soil quality. Biofertilizers are living organisms that have an ability to mobilize nutrients from unusable form 
through biological process and these groups of microorganisms may either fix atmospheric nitrogen or solubilise insoluble phosphorus and make them available for crops. Azospirillum, Phosphobacteria, VAM, Azotobacter, Rhizobium etc., are the main types of organisms widely recommended for many field crops. Biofertilizers were found to have positive impact to soil fertility resulting in an increase in crop yield without causing any type of environmental wastes or soil hazards. Various studies proved that significant improvement in growth and yield and quality of vegetables with different biofertilizer applications on various crop (Yadav et al., 2001 \& Sanjukta Biswas, 2014). Similarly, application of organic manure, vermicompost and biofertilizer combinations has led to quality agricultural products (Sanchez et al., 2008 and Velmurugan et al., 2008).

Coriander (Coriandrum sativum L.) is one of the most important of vegetable, spice and medicinal plant which belongs to the family Apiaceae (Umbelliferae) is mostly cultivated from its seeds throughout the year. India is the major producer, consumer and exporter of coriander in the world with an annual production of approximately (1000 metric tonnes in 2019). This plant is very much aromatic and has several uses in food and in other industries. Plants have played a major role in maintaining human health and civilizing the value of human life for thousands of years (Dhankar et al., 2011). It is also used to perfumes a usages. All parts of plant are edible, fresh leaves can be used for garnishing and are common ingredient in many foods like chutneys and salads. The green herb is also engaged for the preparation of either steam distilled essential oil or the solvent extracted oleoresin (Mhemdi et al., 2011). Fresh juice of coriander is tremendously beneficial in therapeutic many deficiencies correlated to vitamins and iron.
Fresh leaves are being used in cooking, flavouring, beverages etc and seeds are used in preparation of value added products (Bhat et al., 2014). It is sometimes used to mask odd flavors (Parthasarathy et al., 2008). Several studies have reported that vermicompost can increase the growth and biomass of some medicinal plants such as chamomile (Fallahi et al., 2008), plantain (Sanchez et al., 2008), coriander (Singh et al., 2009 \& Darzi et al., 2012), fennel (Darzi et al., 2007), cumin (SaeidNejad and Rezvani Moghaddam, 2011), etc. Some other studies have reported that biostimulants such as Azotobacter chroococcum and Azospirillum lipoferum could cause increased growth and biomass in a few medicinal plants such as coriander (Darzi et al., 2012), fennel (Mahfouz and Sharaf Eldin, 2007), turmeric (Velmurugan et al., 2008) etc,.The present study was carried out with a aim to evaluate the effect of vermicompost along with bioinoculants with due regards to growth, and biomass for coriander. The growth parameters were expressed as number of leaves, fresh weight and dry weight.

\section{Materials and Methods}

The experiment was carried out at National Institute of Plant Health Management, Rajendranagar during the period of December 2019 to January 2020. The experimental field were ploughed two times and divided into 7 plots. Each plots were $3 \mathrm{~m}$ long and $2 \mathrm{~m}$ wide in which the coriander seeds (local hybrid variety) were transplanted in seven rows. The experiment was conducted in an irrigated plots. One week old vermicompost (VC), Dry compost from kitchen wastes and composted Farm Yard Manure (FYM) was used as organic manure for the experiment. Further, mixture of bioinoculants (Biofertilizer (BF)Azotobacter, Phosphorus Solubilising Bacteria and Biopesticides (BP) (Trichoderma and Pseudomonas) were 
admixed with the organic manures. All of these manures and bio fertilizers were produced at NIPHM. The experiment consists of seven treatments as follows:

All organic manures VC, FYM, dry compost were added @ $0 \mathrm{~kg}$ per experimental plot at two times (one at the time of land preparation and another at on 5 DAS). The bio inoculants were applied along with vermicompost and FYM (@2g $/ \mathrm{kg}$ ) during transplanting of seedlings and 5 DAS in the experimental fields. Out of 7 rows, the middle 4 rows were selected for the collection of data to avoid the effect of other environmental factors. In each row 10 plants from each row was selected randomly $(10 \mathrm{x} \quad 4$ rows $=40$ plants $)$ and uprooted to determine the following characters from each experimental plot - plant height, root length, number of leaves/plant, fresh weight and dry weight of the plants on $15^{\text {th }}$ and $30^{\text {th }}$ day of planting. The chlorophyll content in the leaves was measured by chlorophyll meter after the harvest of the plant $\left(30^{\text {th }}\right.$ day $)$.

The roots were cleaned carefully to remove adhering soil particles. After the harvest the plants were dried in oven at $65^{\circ} \mathrm{C}$ for 72 hours and dry weights were recorded in all the treatments. Total yield was measured based the total fresh weight of plant after the harvest $\left(30^{\text {th }}\right.$ day).One-way analysis of variance (ANOVA) and Duncan's t multiple ranged test were used to identify the homogenous type of the data sets among different treatments for different plant parameters in different treatments.

\section{Results and Discussion}

Effect of different organic composts are admixed with bio inoculants on morphological characters such as plant height, number of leaves, root length, fresh weight and dry weight of the coriander crop is given in Table 2.The data tested by ANOVA followed by Duncun test revealed that significant difference in plant growth parameters such as plant height $(F=113.73$, $P<0.001$ at 15 DAS $\& F=112.09, P<0.001$ at 30 DAS $)$, no of leaves/plant $(F=55.54$, $P<0.001$ at 15 DAS $\& F=45.56, P<0.001$ at 30 DAS), root length $(F=55.12, P<0.001$ at 15 DAS $\& F=58.79, P<0.001$ at 30 DAS), fresh weight $(F=4.58, P<0.001$ at $30 \mathrm{DAS})$ and dry weight $(F=24.43, P<0.001$ at 30 DAS $)$ was among the treatments. Photo.1 showed the growth parameters of different treatments.

\section{Plant Height (cm)}

Among the different treatment, the highest mean plant height $(\mathrm{cm})$ was recorded in $\mathrm{T} 1$ $(12.87 \pm 2.14)$, and $\mathrm{T} 4(11.28 \pm 1.22)$ and lowest plant height $(4.68 \pm 0.94 \mathrm{~cm})$ was observed in T7 (control) at 15 DAS of coriander plant. While at 30 DAS the highest mean plant height was recorded in three treatments $\mathrm{T} 1(20.25 \pm 1.89)$ followed by $\mathrm{T} 4$ $(20.15 \pm 2.46) \approx \mathrm{T} 5(20.00 \pm 2.39)$ and lower plant height exhibited in control plot $\mathrm{T} 7$ (11.27 \pm 1.13$)$ (Table 2).

\section{Root Length (cm)}

The mean length of root length $(\mathrm{cm})$ varied significantly among the different treatments when compared to control plot both at $15 \&$ 30 DAS. The maximum root length (5.05 \pm 1.23 ) was achieved in $\mathrm{T} 1$ followed by $\mathrm{T} 4$ $(4.23 \pm 0.88) \approx \mathrm{T} 5(4.12 \pm 1.32)$ and minimum root length observed in control $(1.75 \pm 0.56)$ at 15 DAS. Similarly, the maximum root length was found from T1 $(6.69 \pm 1.09)$ which was statistically identical with T3 $(5.93 \pm 1.04) \approx$ T5 (5.73 \pm 0.95$)$ while minimum from T7 $(3.16 \pm 0.54)$ at 30 DAS (Table 2).

\section{Leaves Number (nos.)}

Statistically significant variation was found among the treatments for number of leaves. Duncan's multiple range tests on mean 
maximum number of leaves was found from $\mathrm{T} 1$ (6.02 \pm 0.94$), \mathrm{T} 4(5.92 \pm 1.24), \mathrm{T} 3(5.75 \pm$ $1.33)$, T5 (5.62 \pm 1.12$)$ and T6 (5.60 \pm 0.95$)$ followed by T2 (4.82 \pm 0.71$)$ whereas minimum from $\mathrm{T} 7(2.62 \pm 0.58)$ at $15 \mathrm{DAS}$. However, the performance order of effect of different treatment on mean number of leaves per plant were $\mathrm{T} 1(10.05 \pm 2.48) \approx \mathrm{T} 4(10.05 \pm$ $2.48) \approx \mathrm{T} 3(10.02 \pm 2.33)>\mathrm{T} 5(9.42 \pm 1.83)$ $>\mathrm{T} 6(8.42 \pm 1.64)>\mathrm{T} 2(7.40 \pm 0.9)>\mathrm{T} 7$ $(5.72 \pm 0.75)$ at 30 DAS (Table 2).

\section{Fresh weight of Plant (g)}

The ANOVA based Duncun test showed the highest fresh weight (g) of plant were obtained in 5 treatments $(\mathrm{T} 1=0.80 \pm 0.07$; $\mathrm{T} 4=0.79 \pm 0.04 ; \mathrm{T} 5=0.78 \pm 0.18 ; \mathrm{T} 3=0.78 \pm$ 0.05 and $\mathrm{T} 6=0.71 \pm 0.18$ ) followed by $\mathrm{T} 2$ $(0.70 \pm 0.15)$. The lowest fresh weight of plant $(0.60 \pm 0.25)$ was obtained in $\mathrm{T} 7$ (Control).

\section{Dry weight of Plant (g)}

Significant increase in dry weight of plant was observed among the different treatments. The highest dry weight of plant (g) were obtained in T1with a mean value of $0.30 \pm$ $0.12 \mathrm{~g}$ and less in the control treatment (T7) with value of $0.09 \pm 0.00$ (Table 2). The present results show that the interaction of vermicompost and bio inoculant was significant.

\section{Chlorophyll Content}

One way analysis of variance test on chlorophyll content $(\mathrm{g} / \mathrm{kg})$ revealed significant differences among different types of treatment $(F=60.98, P<0.001$ at 30 DAS $)$. The maximum and minimum average chlorophyll Content $(\mathrm{g} / \mathrm{kg})$ was in $\mathrm{T} 1$ (21.50) and T7 (14.13), respectively. The Chlorophyll Content in coriander plant was in the order: $\mathrm{T} 1(21.50)>\mathrm{T} 5$ (19.24) > T6 (18.72) > T2 $(17.92)=\mathrm{T} 3(17.62)>\mathrm{T} 4(16.98)>\mathrm{T} 7$ (13.38)(Figure 1).

\section{Total Yield}

Effect of different treatment on coriander yield based on the total weight $(\mathrm{kg})$ measured after the harvest was presented in Figure 2. Significant increase in the yield of $1.66 \mathrm{~kg}$ was the recorded from plot treated with vermicompost + biofertilizers + biopesticides (T1). Followed by T4 $(1.56 \mathrm{~kg})>\mathrm{T} 5$ (1.45 $\mathrm{kg})>\mathrm{T} 3(1.40 \mathrm{~kg})$ yield better results. The poorest yield was received from the control plot $(0.825 \mathrm{~kg})$.

Table.1 Treatment design with bioinoculants

\begin{tabular}{|l|l|}
\hline Treatments & Combination \\
\hline T1 - VC+BF+ BP & Vermicompost + Biofertilizers + Biopesticides \\
\hline T2 - FYM+BF+BP & Farm Yard Manure + Biofertilizers + Biopesticides \\
\hline T3 - VC+FYM+BF+BP & $\begin{array}{l}\text { Vermicompost + Farm Yard Manure + Biofertilizers + } \\
\text { Biopesticides }\end{array}$ \\
\hline T4 - VC+FYM+VW & Vermicompost + Farm Yard Manure + Vermiwash \\
\hline T5 - Dry compost & Dry compost from vegetable waste \\
\hline T6 -Vermicompost & Vermicompost \\
\hline T7 - Control & No treatment \\
\hline
\end{tabular}


Table.2 Effect of vermicompost and other organic manures on morphological parameter of coriander

\begin{tabular}{|c|c|c|c|c|c|c|c|c|}
\hline \multirow[t]{2}{*}{ Treatments } & \multicolumn{2}{|c|}{$\begin{array}{l}\text { Height of plant }(\mathrm{cm}) \\
\quad(\text { mean } \pm \text { SD })\end{array}$} & \multicolumn{2}{|c|}{$\begin{array}{l}\text { Root length }(\mathrm{cm}) \\
\quad(\text { mean } \pm \text { SD })\end{array}$} & \multicolumn{2}{|c|}{$\begin{array}{l}\text { No.of leaves /plant } \\
\quad(\text { mean } \pm \text { SD })\end{array}$} & \multirow{2}{*}{$\begin{array}{c}\text { Fresh weight } \\
\begin{array}{c}(\text { gm) } \\
(\text { mean } \pm \text { SD) }\end{array} \\
30 \text { days }\end{array}$} & \multirow{2}{*}{$\begin{array}{c}\begin{array}{c}\text { Dry weight } \\
(\text { gm) }\end{array} \\
\begin{array}{c}\text { (mean } \pm \text { SD) } \\
30 \text { days }\end{array}\end{array}$} \\
\hline & 15 days & 30 days & 15 days & 30 days & 15 days & 30 days & & \\
\hline $\mathrm{T} 1-\mathrm{VC}+\mathrm{BF}+\mathrm{BP}$ & $12.87 \pm 2.14^{\mathrm{a}}$ & $20.25 \pm 1.89^{\mathrm{a}}$ & $5.05 \pm 1.23^{\mathrm{a}}$ & $6.69 \pm 1.09^{a}$ & $6.02 \pm 0.94^{\mathrm{a}}$ & $10.57 \pm 2.21^{\mathrm{a}}$ & $0.80 \pm 0.07^{\mathrm{a}}$ & $0.30 \pm 0.12^{\mathrm{a}}$ \\
\hline T2-FYM+BF+BP & $10.95 \pm 1.13^{b}$ & $17.20 \pm 2.05^{b}$ & $2.53 \pm 0.86^{\mathrm{d}}$ & $4.12 \pm 1.09^{c}$ & $4.82 \pm 0.71^{b}$ & $8.42 \pm 1.64^{c}$ & $0.70 \pm 0.15^{c}$ & $0.11 \pm 0.02^{c}$ \\
\hline T3 VC+FYM+BF+BP & $11.28 \pm 1.22^{\mathrm{a}}$ & $19.80 \pm 2.25^{\mathrm{a}}$ & $3.06 \pm 0.89^{c}$ & $5.93 \pm 1.04^{\mathrm{a}}$ & $5.75 \pm 1.33^{\mathrm{a}}$ & $10.02 \pm 2.33^{\mathrm{ab}}$ & $0.78 \pm 0.05^{\mathrm{ab}}$ & $0.12 \pm 0.02^{c}$ \\
\hline T4-VC+FYM+VW & $10.32 \pm 1.73^{b}$ & $20.15 \pm 2.46^{\mathrm{a}}$ & $4.23 \pm 0.88^{b}$ & $5.34 \pm 1.19^{b}$ & $5.92 \pm 1.24^{\mathrm{a}}$ & $10.05 \pm 2.48^{\mathrm{ab}}$ & $0.79 \pm 0.04^{\mathrm{a}}$ & $0.25 \pm 0.12^{b}$ \\
\hline T5-Dry compost & $10.17 \pm 1.23^{b}$ & $20.00 \pm 2.39^{\mathrm{a}}$ & $4.12 \pm 1.32^{b}$ & $5.73 \pm 0.95^{\mathrm{a}}$ & $5.62 \pm 1.12^{\mathrm{a}}$ & $9.42 \pm 1.83^{b}$ & $0.78 \pm 0.18^{\mathrm{a}}$ & $0.16 \pm 0.06^{b}$ \\
\hline T6-Vermicompost & $9.75 \pm 1.54^{\mathrm{b}}$ & $15.19 \pm 1.88^{c}$ & $2.76 \pm 0.93^{\mathrm{d}}$ & $4.74 \pm 0.64^{c}$ & $5.60 \pm 0.95^{\mathrm{a}}$ & $6.40 \pm 0.90^{\mathrm{d}}$ & $0.71 \pm 0.18^{b}$ & $0.14 \pm 0.07^{b}$ \\
\hline T7- Control & $4.68 \pm 0.94^{c}$ & $11.27 \pm 1.13^{\mathrm{d}}$ & $1.75 \pm 0.56^{\mathrm{e}}$ & $3.16 \pm 0.54^{d}$ & $2.62 \pm 0.58^{c}$ & $5.72 \pm 0.75^{d}$ & $0.60 \pm 0.25^{\mathrm{c}}$ & $0.09 \pm 0.00^{\mathrm{d}}$ \\
\hline
\end{tabular}

Significant differences $(P<0.05)$ are indicated by different letters

The values are represented a mean + Standard deviation of 20 samples

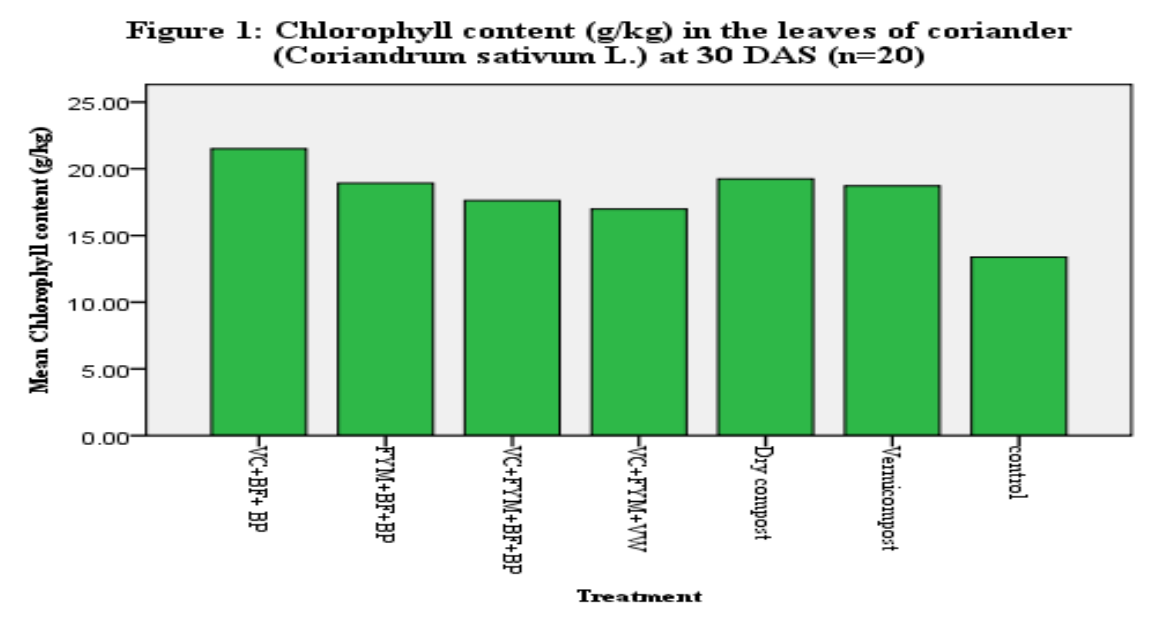



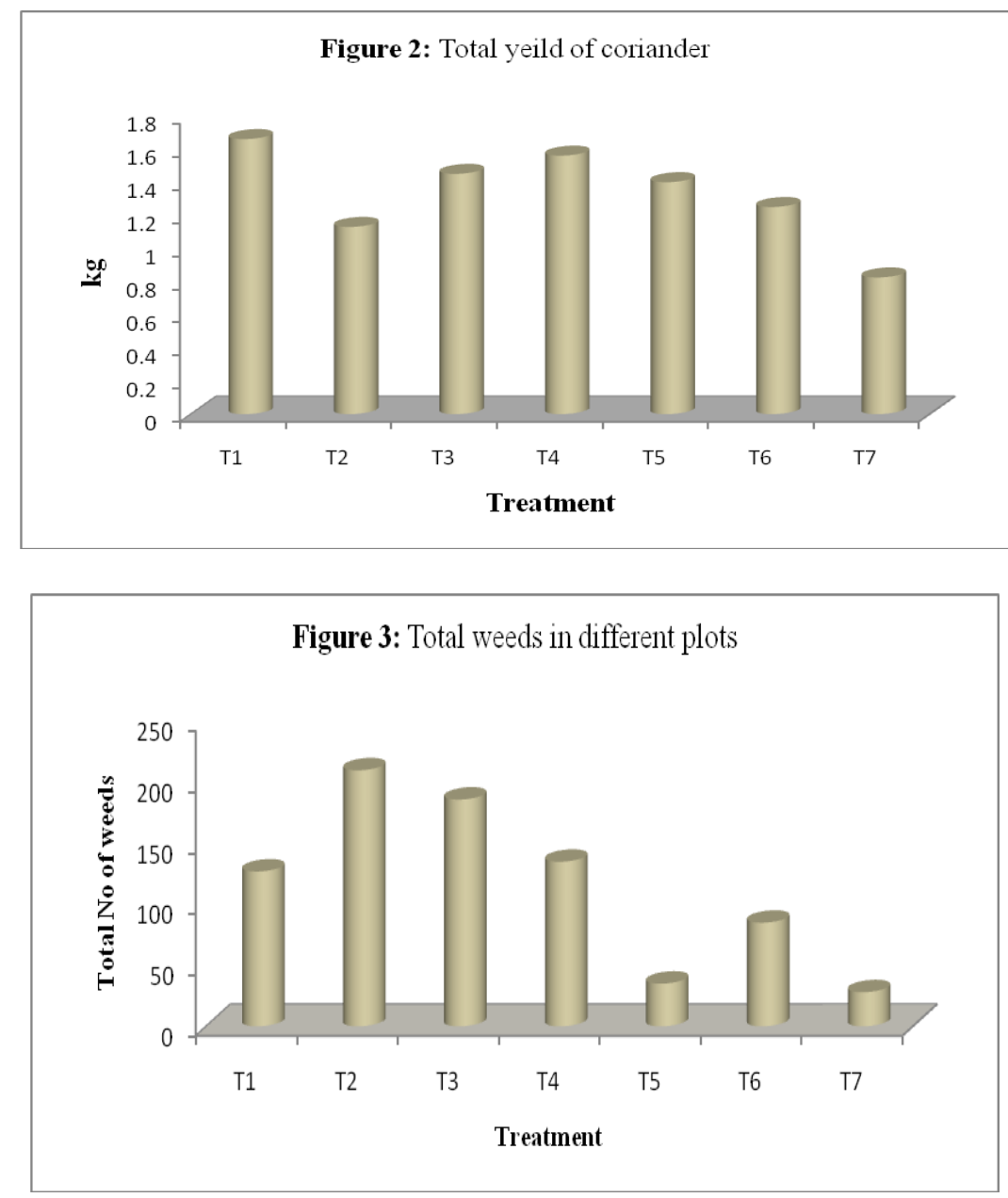

Photo.1 Effect of different treatments on plant growth parameters

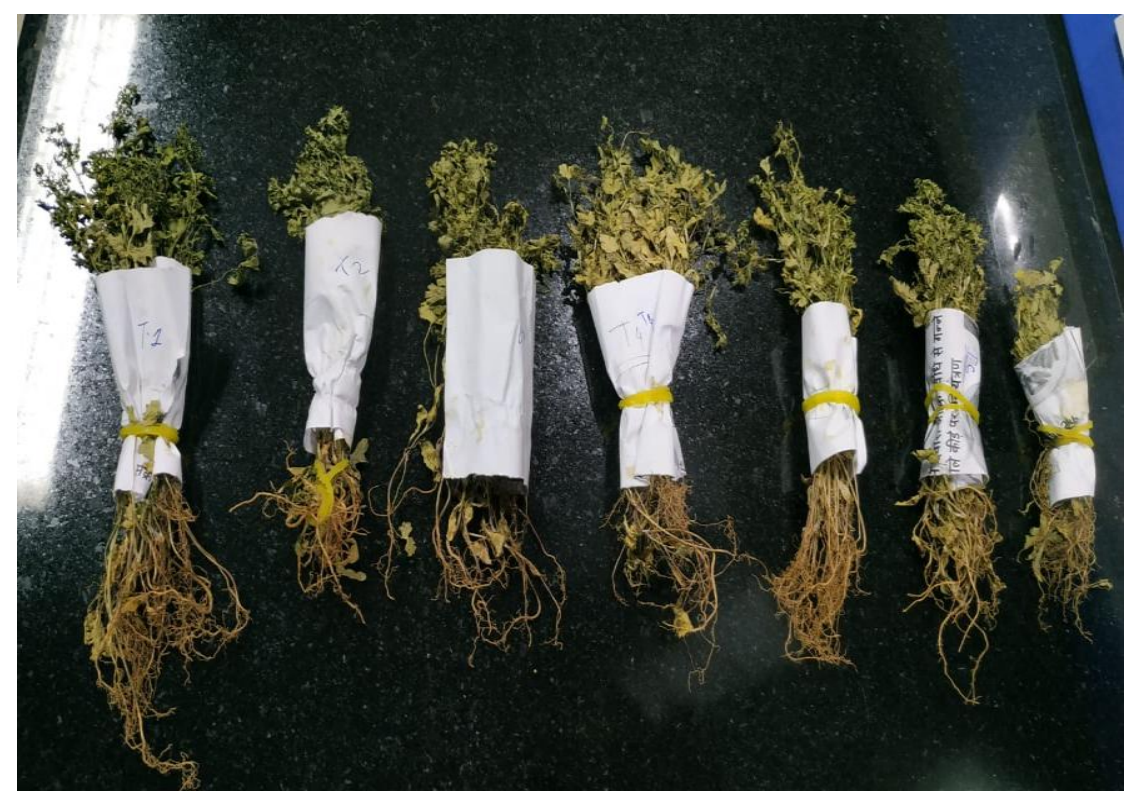




\section{Weed intensity}

The weed intensity was measured after harvesting of the plants based on presence of total count in the experimental plots are 127, 210, 186, 135, 35,85, 28 in T1, T2, T3, T4, T5, T6, T7 respectively (Figure 3).

Among the various treatment used in the study, the significant effect on the growth parameter of coriander crop i.e plant height, no. of leaves, root length, fresh weight and dry weight as well as chlorophyll content were enhanced by the organic manures especially with vermicompost admixed with bio inoculant than the untreated plots (control). This might be due to excellent supply of better nutrients and plant growth promoters to the plants which is present in the worm casts. The vermicompost with a relatively high content of humus-like compounds, active microorganisms and enzymes, greatly contribute to the enhancement of the biochemical fertility of soils degraded by intensive - cultivation, pollution or natural causes (Perucci, 1992). The casts of earthworm is one of the most useful and active agent in introducing suitable chemical, physical and microbiological changes in the soil and, thereby, directly increasing the fertility and crop producing power in the soil (Joshi and Kelkar, 1951).

There are many reports that vermicompost increased the growth and yield of different plants viz., rice (Gandhi and Sivakumar, 2010), garden pea (Meena et al., 2007), cabbage (Mulusew Getnet and Nagappan Raja, 2013), wheat (Nijhawan and Kanwar, 1951), tomato (Hossein Alidadi, et al., 2014), coconut (Thomas et al., 2012).Green gram (Manoharan and Ganesamoorthi, 2015), Brinjal (Maya and Satish, 2015), Garllic (Surindra Suthar, 2009). A study by Tomati et al., (1983) revealed that positive effect of vermicompost on the growth of Begonias and
Coleus, especially a stimulation of rooting, time of flowering, lengthening of internode.

The chlorophyll is an integral component of plant pigments and plays a main role in the process of photosynthesis. It is the molecule that absorbs sunlight and uses its energy to synthesis carbohydrates from $\mathrm{CO} 2$ and water. It also plays an important role in ATP synthesis (Kochot et al., 1998 and Ravimycin, 2016). The increased chlorophyll content to the vermicompost application was recorded in the present study. Further, a study by Maya and Satish (2015) showed that the significant increase was observed in the brinjal plants which were sprayed with vermiwash and also added in the soil treatment. Study conducted by Thenmozhi, et al., (2010), shows that bioinoculants viz., Azospirillum and Pseudomonas, and organic manure as vermicompost had influenced the shoot and root length, plant biomass and number of leaves in Amaranthus retroflexus. A study by Ravimycin (2016) reported that application of vermicompost increased all the morphological, pigment, protein and nutrient content in coriander plants when compared to FYM and control treatment. Gandhi and Sivakumar (2010) reported that the combined form of inoculation of vermicompost increased the in rice grain quality like hulling percentage, milling percentage of grain and water uptake, volume expansion, elongation ratio, protein and amylose of rice kernel. It was reported that the combined inoculation of bioinoculants increased the number of panicle per plant (Yanni and El-Fattah, 1999 \& Shanmugam and Veeraputhran, 2000). In the present work also similar trend was observed in T1 and T4.Hence, vermicompost with bioinoculants combination or vermicompost + FYM + vermiwash combination to be an effective organic fertilizer which contributes the growth of plants and helps in production of coriander crop. 
In conclusion the results revealed that application of vermicompost in combination with microbial inoculums gave excellent results on the plant growth and yield parameter when compared with other treatments followed by T4, T3 and T5 also yielded better results over the control plot. Therefore, the vermicompost and enriched with bio inoculants or Vermicompost $(50 \%)+$ FYM $(50 \%)+$ Vermiwash may be used as plant growth media for sustainable coriander crop production.

\section{Acknowledgements}

Authors are highly thankful to Smt. G. Jayalakshmi, IAS, Director General, National Institute of Plant Health Management for the encouragement and funding to conduct the experiments. The kind cooperation of $\mathrm{Mr}$. Pawar JRF (PHM) during whole research period is highly acknowledged.

\section{References}

Bhat, S., Kaushal, P.,Kaur, M. and Sharma, H. K. 2014. Coriander (Coriandrum sativum L.): Processing, nutritional and functional aspects. African Journal of Plant Science, 8(1): 25-33.

Darzi, M.T., Ghalavand, A., Rejali, F. and Sephidkon, F.2007.Effects of Biofertilizers Application on yield and yield components in fennel (Foeniculum vulgare Mill.). Iranian Journal of Medicinal and Aromatic Plants, 22(4): 276-292.

Darzi, M.T., Haj Seyed Hadi, MR. and Rejali, F.2012. Effects of Cattle Manure and Biofertilizer Application on Biological Yield, Seed Yield and Essential oil in Coriander (Coriandrum sativum). Journal of Medicinal Plants, 9(11): 7790.

Dhankar, S., Kaur, R., Ruhil, S., Balhara, M., Dhankhar, S. andChhillar, A.K.2011.A review on Justicia adhatoda - A potential source of natural medicine. African Journal of Plant Science, 5(11):620-627.

Fallahi, J., Koocheki, A.and Rezvani Moghaddam P.2008. Investigating the effects of organic fertilizer on quantity index and the amount essential oil and chamazulene in chamomile (Matricaria recutita).Agricultural Research: Water, Soil and Plant in Agriculture, 1(8): 157168.

Gandhi, A. and Sivakumar, K. 2010. Impact of vermicompost carrier based bioinoculants on the growth, yield and quality of rice (Oryza sativa L.) C. V. NLR 145. The Ecoscan, 4(1):83-88.

HosseinAlidadi, Ali Reza Saffari, Damon Ketabi, RoyaPeiravi and Ahmad Hosseinzadeh.2014. Comparison of Vermicompost and Cow Manure Efficiency on the Growth and Yield of Tomato Plant. Health Scope, 3(4): e14661.

Joshi, N.V. and Kelkar, B.V. 1951. The role of earthworms in soil fertility. Indian Journal ofAgriculture Sciences, 21 (4):189-196.

Kaur, P., Bhardwaj, M. and Babbar, I. 2015.Effect of Vermicompost and Vermiwash on Growth of Vegetables. Research Journal of Animal, Veterinary and Fishery Sciences, 3(4): 9-12.

Kochot, C.K., Golbale, S.B. and A. Purohit, 1998.In: Textbook of pharmacognosy, NiraliPrakashan, Pune, pp. 17-18.

Mahfouz, S.A. and SharafEldin, M.A.2007.Effect of mineral vs. biofertilizer on growth, yield, and essential oil content of fennel (Foeniculum vulgare Mill). International agrophysics, 21(4): 361366.

Manoharan, K. and Ganesamoorthi, R. 2015.Nutrient status and plant growth promoting potentiality of vermicompost 
and biocompost on Vigna radiata. World Journal of Pharmacy and Pharmaceutical Sciences, 4(8):830-838.

Maya, M.J. and Satish, A.B. 2015. Effect of Vermiwash on the Growth Parameters of Solanum melongena L. (Brinjal Plant). International Journal of Current Research in Biosciences and Plant Biology, 2(9): 24-29.

Meena, R.N., Singh, Y., Singh, S.P., Singh, J.P. and Singh, K. 2007. Effect of sources and level of organic manure on yield: Quality and economics of garden pea (PisumsativumL.) in Eastern Uttar Pradesh. Vegetation Science, 34(1): 6063.

Mhemdi, H., Rodier, E., Kechaou, N. and Fages, J. 2011.A supercritical tuneable process for the selective extraction of fats and essential oil from coriander seeds. Journal of Food Engineering, 105(4):609-616.

MulusewGetnet and Nagappan Raja. 2013. Impact of Vermicompost on Growth and Development of Cabbage, Brassica oleracea Linn. and their Sucking Pest, Brevicoryne brassicae Linn. (Homoptera: Aphididae). Research Journal of Environmental and Earth Sciences, 5(3): 104-112.

Nijhawan, S.D. and Kanwar, J.S., 1951.Physio-chemical properties of earthworm casting and their effect on the productivity of soil.India Journal of Agriculture Sciences, 22 (4), 357-373.

Palanichamy, V., Mitra, B., Reddy, N., Katiyar, M., Rajkumari, R.B., Ramalingam, C. and Aranganthan, C. 2011.Utilizing food waste by vermicomposting, extracting vermiwash, castings and increasing relative growth of plants. International Journal of Chemical and Analytical Science, pp. 1241-1246.

Parthasarathy, VA., Chempakam, B. and Zachariah, TJ. 2008. Coriander:
Chemistry of Spices, $C A B$ International, 190-206. doi:10.1079/9781845934057.019013.

Perucci, P. 1992. Enzymes activity and microbial biomass in field soil amended with municipal refuse. Biology \& Fertility of Soils, 14: 54-60.

Rathore, MS., Singh, M., Panwar, D. and Shekhawat, N.S. 2007. Vermicomposting: Towards Clean and Green Farming. Green Farming, 1(1): 28-30.

Ravimycin, T. 2016. Effects of Vermicompost (VC) and Farmyard Manure (FYM) on the germination percentage growth biochemical and nutrient content of Coriander (Coriandrum sativum L.).International Journal of Advanced Research in Biological Sciences,3 (6): 91-98.

SaeidNejad, AH. and Rezvani Moghaddam, P.2011. Evaluation of compost, vermicompost and cattle manure application on yield, yield components and essential oil percent in cumin (Cuminum cyminum). The Journal of Horticultural Sciences, 24(2): 142-148.

Sanchez,GE.,Carballo, GC. and Ramos, GSR. 2008. Influence of organic manures and biofertilizers on the quality of two Plantaginaceae: Plantago major L. and Plantago lanceolata L. RevistaCubana de Plantas Medicinales, 13(1): 12-15.

SanjuktaBiswas. 2014. Influence of microbial enriched vermicompost on the growth and nutrient content of Amaranthus cruentus L.I nternational Journal of Scientific Research, 3 (9):2277-8179.

Shanmugam, P. M. and Veeraputhran, R. 2000. Effect of organic manure, biofertilizers, inorganic nitrogen and zinc on growth and yield of rabi rice (Oryza sativa L.). Madras Agricultural journal, 87(1/ 3): 90-93.

Singh, B., Singh, B., Masih, MR. and Choudhari RL. 2009. Evaluation of P 
and $\mathrm{S}$ enriched organic manures and their effect on seed yield and quality of coriander (Coriandrum sativum). International Journal of Agricultural Sciences, 5(1): 18-20.

Sinha, R.K., Agarwal, S., Chaudhan, K. and Valani, D. 2010. The wonders of earthworms and its vermicomposting in farm production: Charles Darwin's friends of farmers', with potential to replace destructive chemical fertilizers from agriculture. Agricultural Science, 1(2): 76-94.

Surindra Suthar. 2009. Impact of vermicompost and composted farmyard manure on growth and yield of arlic (Allium stivum L.) field crop. International Journal of Plant Production, 3(1): 27-38.

Thenmozhi, R., Rejina, K., Madhusudhanan, K. and Nagasathya, K. 2010. Study on effectiveness of various biofertilizers on the growth and biomass production of selected vegetables. Research Journal of Agriculture and Biological Sciences, 6(3):296-301.

Thomas, G.V., Palaniswami, C., Gopal, M. and Gupta, A.. 2012. Recycling coconut leaf-agro wastes mixture using Eudrilus $s p$. and growth promotion properties of coconut leaf vermicompost.
International Journal of Innovative Horticulture. 1(2):113-118.

Tomati, U., Grappelli, A. and Galli, E. 1983.Fertility factors in earthworm humus. Proceeding of the International Symposium on Agricultural Environment. Prospects in Earthworm Farming. Publication Search for the Root of the Ministry of Science and Technology (Italian), Rome, pp: 49-56.

Velmurugan, M., Chezhiyan, N. and Jawaharlal, M. 2008. Influence of organic manures and inorganic fertilizers on cured rhizome yield and quality of turmeric (Curcuma longa L.) cv. BSR-2. International Journal of Agricultural Sciences, 4(1): 142-145.

Yadav, V.S., Yadav, B.D. and Sharma, Y.K. 2001. Effect of NICAST (organic manure) in comparison to recommended doses of manure and fertilizers in cabbage. South Indian Horticulture. 49: 157-159.

Yanni, Y. G. and El-Fattah, F. K. A. 1999. Towards integrated biofertilization management with free living and associative dinitrogen fixers for enhancing rice performance in the Nile delta. Syambiosis (Rehovot), 27(3/4): 319-331.

\section{How to cite this article:}

Sakthivel, P., Alice R. P. Sujeetha, G. Ravi, A. G. Girish and Punnam Chander, P. 2020. Effect of Vermicompost with Microbial Bio Inoculums on the Growth Parameter of Coriander (Coriandrum sativum L.). Int.J.Curr.Microbiol.App.Sci. 9(08): 613-622.

doi: https://doi.org/10.20546/ijcmas.2020.908.068 